\title{
BENIGN PAROXYSMAL POSITIONAL VERTIGO (BPPV)
}

\author{
Alifia Firdiansari \\ Fakultas Kedokteran, Universitas Mataram, Indonesia. \\ Email: firdiansarialifia@gmail.com
}

\begin{abstract}
Abstrak
BPPV merupakan suatu kondisi terjadinya gangguan dari sistem perifer vestibular, ketika pasien merasakan sensasi pusing berputar dan berpindah yang berhubungan dengan nistagmus ketika posisi kepala berubah terhadap gaya gravitasi dan disertai gejala mual,muntah dan keringat dingin. Penulisan artikel ini mencakup berbagai sumber yang berasal dari jurnal ilmiah dan pedoman pemerintah maupun instansi terkait. Pencarian sumber dilakukan di portal online publikasi jurnal seperti MedScape, Google Scholar (scholar.google.com) dan National Center for Biotechnology Information (ncbi.nlm.nih.gov), dengan kata kunci "Benign paroxysmal positional vertigo (BPPV)". BPPV ditandai dengan episode vertigo yang tiba-tiba dan singkat yang dipicu oleh gerakan kepala tertentu yang biasanya terjadi akibat perpindahan kristal kalsium-karbonat atau otokonia di dalam kanalis semisirkularis berisi cairan di telinga bagian dalam. Diagnosis BPPV dapat ditegakkan berdasarkan anamnesis dan pemeriksaan fisik yang meliputi beberapa tes antara lain Dix-Hallpike. Diagnosis BPPV dapat dibuat melalui riwayat klinis bersama dengan manuver diagnostik. Penatalaksanaan yang sering digunakan adalah non-farmakologis yang meliputi beberapa manuver seperti Epley, manuver Semount dan manuver Lempert.
\end{abstract}

Kata Kunci: Benign paroxysmal positional vertigo (BPPV), Vertigo

\section{Abstract}

$B P P V$ is a condition of disturbance of the peripheral vestibular system, when the patient feels the sensation of spinning and moving associated with nystagmus when the head position changes against gravity and is accompanied by symptoms of nausea, vomiting and cold sweats. The writing of this article includes various sources originating from scientific journals and government guidelines and related agencies. Source searches were carried out on online portals for journal publications such as MedScape Google Scholar (scholar.google.com) and the National Centre for Biotechnology Information/NCBI (ncbi.nlm.nih.gov), with the keyword 'Benign paroxysmal positional vertigo (BPPV)". BPPV is characterized by sudden, brief episodes of vertigo triggered by certain head movements that usually result from displacement of calcium-carbonate crystals or otoconia within the fluid-filled semicircular canals of the inner ear. The diagnosis of BPPV can be made based on anamnesis and physical examination which includes several tests, including the Dix-Hallpike. The diagnosis of BPPV can be made through clinical history along with diagnostic procedures. The management that is often used is nonpharmacological which includes several maneuvers such as the Epley maneuver, the Semount maneuver and the Lempert maneuver. 
Keywords: Benign paroxysmal; positional vertigo (BPPV), Vertigo

Diserahkan: 03-01-2022Ｄiterima: 25-01-2022Ｄiterbitkan: 20-02-2022

\section{Pendahuluan}

Salah satu penyebab paling umum dari vertigo adalah Benign paroxysmal positional vertigo (BPPV). BPPV merupakan suatu kondisi terjadinya gangguan dari sistem perifer vestibular, ketika pasien merasakan sensasi pusing berputar dan berpindah yang berhubungan dengan nistagmus ketika posisi kepala berubah terhadap gaya gravitasi dan disertai gejala mual,muntah dan keringat dingin. Pada populasi umum prevalensi BPPV yaitu antara 11 sampai 64 per 100.000 (prevalensi 2,4\%) (Edward \& Roza, 2014).

Penyakit ini dapat disebabkan baik oleh kanalitiasis ataupun kupulolitiasis dan secara teori dapat mengenai ketiga kanalis semisirkularis, walaupun terkenanya kanal posterior, diikuti bentuk lateral (Dewi \& Mkes, 2019). Diagnosis BPPV dapat ditegakkan berdasarkan anamnesis dan pemeriksaan fisik yang meliputi beberapa tes antara lain Dix-Hallpike. Diagnosis BPPV juga digolongkan menurut tipe-tipe kanal. Penatalaksanaan yang sering digunakan adalah non-farmakologis yang meliputi beberapa manuver seperti Epley, manuver Semount dan manuver Lempert (Balatsouras et al., 2018).

\section{Metode Penelitian}

Metode yang digunakan dalam penulisan artikel ini adalah studi literatur (literature review) yang relevan dari berbagai referensi meliputi jurnal ilmiah, panduan klinis terbaru dari IAUI, situs web, dan buku teks terbaru dan terpercaya mengenai topik Benign Paroxysmal Positional Vertigo (BPPV) (Triandini et al., 2019). Pencarian sumber dilakukan di portal online publikasi jurnal sebanyak 23 sumber yang berasal dari Pubmed (https://pubmed.ncbi.nlm.nih.gov/), Google Scholar (scholar.google.com), Nation Center for Biotechnology Information/ NCBI (ncbi.nlm.nih.gov), dan ResearchGate (https://www.researchgate.net/) dengan kata kunci Benign Paroxysmal Positional Vertigo, tatalaksana BPPV, dan diagnosis BPPV.

\section{Hasil dan Pembahasan}

\section{A. Definisi}

BPPV atau benign paroxysmal positional vertigo merupakan gangguan kesimbangan periver, dengan gejala senasi pusing berputar diikuti dengan mual muntah serta keringat dingin yang berhubungan dengan nistagmus ketika posisi kepala berubah terhadap gravitasi (Lee \& Kim, 2010).

\section{B. Epidemiologi}

Pasa posisi umum prevalensi BPPV yaitu antara 11 sampai 64 per 100.000 (prevalensi 2,4\%). Dari kunjungan 5,6 miliar orang ke rumah sakit dan klinik di United State dengan keluhan pusing didapatkan prevalensi $17 \%$ - 42\% pasien didiagnosis 
BPPV. Dari segi onset BPPV biasanya diderita pada usia 50-70 tahun. Proporsi antara wanita lebih besar dibandingkan dengan laki-laki yaitu 2,2: 1,5. BPPV merupakan bentuk dari vertigo posisional. Insidensi di Indonesia 10-100 kasus pertahun, 20\% kasus memiliki riwayat trauma kepala (Istiqomah et al., 2021).

\section{Etiologi}

Secara umum bersifat ideopatik, namun penyebab terbanyak yaitu trauma kepala. Vertigo pasca trauma kepala dapat terjadi akibat kerusakan telinga bagian dalam, N. VIII, vestibular sentral atau adanya kesalahan pilih input sensoris yang dibutuhkan untuk keseimbangan sempurna (Putri \& Sidharta, 2016).

Terjadi perpindahan kristal kalsium-karbonat atau otokonia di dalam kanalis semisirkularis berisi cairan di telinga bagian dalam. Otoconia ini penting untuk berfungsinya utrikulus membran otolitik dengan membantu membelokkan sel-sel rambut di dalam endolimfe, yang menyampaikan perubahan posisi kepala termasuk memiringkan, memutar, dan akselerasi linier (Picciotti et al., 2020)

\section{Fraktur os Temporal}

Trauma kepala tumpul adalah penyebab utama vertigo pasca trauma, tulang temporal pars petrosa peka terhadap trauma karena sifatnya padat mengandung rongga labirin dan letaknya di dasar tengkorak. Trauma pada telinga dalam dapat atau tidak disertai fraktur tengkorak. (Putri, et al., 2016)

\section{Commotio labirin}

- Fraktur longitudinal merupakan70-90\% fraktur os. temporalis, terbanyak akibat benturan temporo parietal. Garis fraktur mulai puncak piramid os. petrosus melintang tegmen timpani, menghasilkan deformitas seperti tangga dalam meatus acusticus externus telinga tengah dan mengakibatkan dislokasi rantai tulang pendengaran.

- Fraktur Transversal merupakan 10-30\% fraktur os. temporal menyilang sumbu panjang piramid os. petrosa dan biasanya akibat benturan oksipital. Garis fraktur menyeberangi fossa posterior ke fossa cranii posterior dan dapat mengenai tulang labirin (bila letaknya lateral) atau merusak MAE yang mengakibatkan kerusakan nervus VII dan nervus VIII (bila letak medial).

Commotio labirin mengakibatkan munculnya gangguan auditori dan vestibuler yang terjadi setelah trauma kepala tumpul tanpa fraktur. Gangguan vestibuler dan auditori terjadi akibat perdarahan mikroskopis koklea dan labirin.

BPPV dapat disebabkan oleh commotio labirin atau pengaruh mekanik langsung trauma kepala pada organ otolith, dengan hilangnya otokonia yang meliputi bahan gelatin dan membran otolith. Hasil degenerasi dari otokonia dapat menempati kanalis semiserkularis posterior dan menyebabkan serangan vertigo singkat sehubungan dengan gerakan kepala. (Putri, et al., 2016)

\section{Patofisiologi}

Bagian vestibular terdiri dari dua komponen yaitu kanalis semisirkularis dan organ otolith. Semi sirkularis terdri dari tiga kanal, yakni kanal anterior, posterior, dan horisontal. Setiap kanal semisirkular terisi oleh endolimfe dan pada bagian dasarnya 
terdapat tonjolan yang disebut sebagai ampula. Ampula punya fungsi mengatur keseimbangan dinamis, yang menentukan kesadaran posisi kepala saat terjadi gerakan memutar atau rotasi (Soepardi et al., 2007).

Sruktur otolith terdiri dari utrikulus dan sakulus yang mendeteksi akselerasi linear, termasuk deteksi terhadap gravitasi. Organ reseptornya adalah makula. Pada setiap makula terdapat sel rambut yang mengandung endapan kalsium yang disebut otolith (otokonia). Makula pada utrikulus diperkirakan sebagai sumber dari partikel kalsium yang menjadi penyebab BPPV (Arinda et al., n.d.).

Benign Paroxysmal Positional Vertigo disebabkan ketika otolith yang terdiri dari kalsium karbonat yang berasal dari makula pada utrikulus yang lepas dan bergerak dalam lumen dari salah satu kanal semisirkular. Kalsium karbonat dua kali lebih padat dibandingkan endolimfe, sehingga bergerak sebagai respon terhadap gravitasi dan pergerakan akseleratif lain (Risa \& Fauziah, 2021). Ketika kristal kalsium karbonat bergerak dalam kanal semisirkular (kanalitiasis), mereka menyebabkan pergerakan endolimfe yang menstimulasi ampula pada kanal yang terkena, sehingga menyebabkan vertigo (Rachmawati et al., 2021).

\section{Manifestasi Klinis}

- Vertigo / sensasi berputar yang dipicu karena perubahan posisi kepala, dirasakan cukup berat, berlangsung singkat hanya beberapa detik (10-30detik).

- Mual dan muntah

- Keringat dingin

\section{Diagnosis}

Kepala pasien diminta untuk berbalik 45 derajat secara horizontal berhadapan dengan penguji dalam posisi duduk,lalu pasien mulai dengan cepat berada di bawah dengan kepala menggantung ditepi meja sekitar 30 derajat horizontal kebawah. Penguji diminta untuk mengamati apakah pasien memiliki vertigo dan mengamati nystagmus kanalis posterior kanan. Apabila terdapat hasil yang positif yakni berupa keterlibatan nystagmus kanalis posterior kanan,maka akan ada getaran dan torsi kearah kanan (Priyono \& Nusadewiarti, 2020).

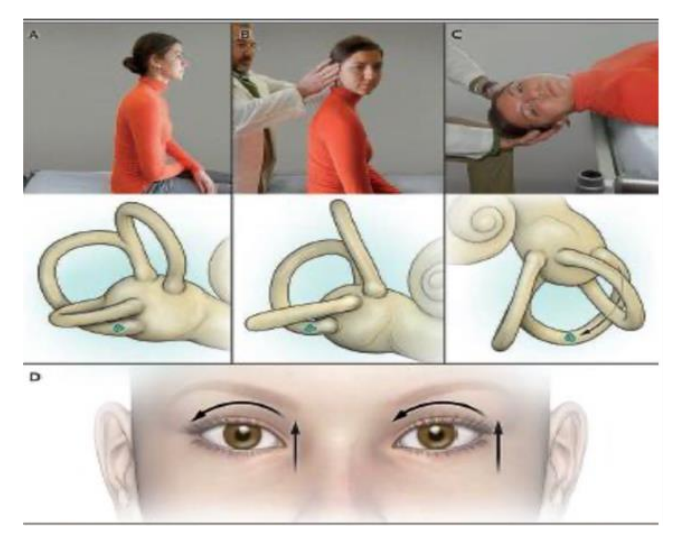

Keterangan Gambar 1: Diposisikan saat pasien duduk tegak (A). Lalu kepala diputar 
45 derajat kearah kanan pasien (B). Kemudian, pasien berubah posisi dari duduk menjadi posisi terlentang dengan kepala menggantung dibawah ujung atas meja pemeriksaan dengan berputar 20derajat (C). Nistagmus yang dihasilkan akan optimis dan torsional menunjukkan hasilnya (D) (Threenesia \& Iyos, 2016)

Untuk dapat menegakan diagnosis klinis BPPV,maka harus memenuhi empat kriteria,yaitu:

1. Vertigo berkaitan dengan karakteristik torsi campuran dan nystagmus vertikal yang telah dilakukan uji dengan Tes Dix- Hallpike

2. Terjadi (biasanya 1 sampai 2 detik) antara selesainya tes Dix-Hallpike dan timbulnya vertigo dan nistagmus.

3. Bersifat paroksismal dari saat timbulnya vertigo dan nystagmus (yaitu, terjadi peningkatan lalu penurunan selama periode 10 sampai 20 detik)

4. Terjadi pengurangan vertigo dan nystagmus apabila tes Dix-Hallpike diulang.

Pada orang normal nistagmus dapat timbul pada saat gerakan provokasi ke belakang, namun saat gerakan selesai dilakukan tidak tampak lagi nistagmus. Pada pasien BPPV setelah provokasi ditemukan nistagmus yang timbulnya lambat, 40 detik, kemudian nistagmus menghilang kurang dari satu menit bila sebabnya kanalitiasis, pada kupulolitiasis nistagmus dapat terjadi lebih dari satu menit, biasanya serangan vertigo berat dan timbul bersamaan dengan nistagmus. (Threenesia \& Iyos, 2016)

\section{E. Tatalaksana}

Non farmakologi yaitu dengan manuver :

- Manuver Epley

Manuver Epley adalah yang paling sering digunakan pada kanal vertikal. Pasien diminta untuk menolehkan kepala ke sisi yang sakit sebesar 450, lalu pasien berbaring dengan kepala tergantung dan dipertahankan 1-2 menit. Lalu kepala ditolehkan 900 ke sisi sebaliknya, dan posisi supinasi berubah menjadi lateral dekubitus dan dipertahan 30-60 detik. Setelah itu pasien mengistirahatkan dagu pada pundaknya dan kembali ke posisi duduk secara perlahan (Edward \& Roza, n.d.)

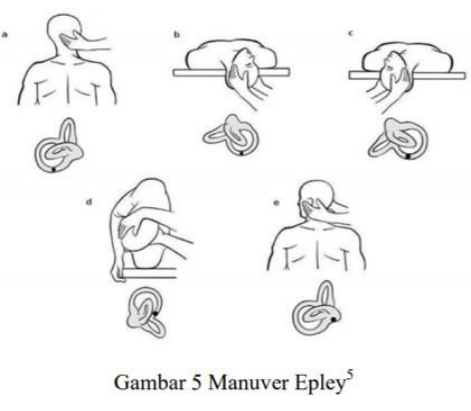

- Manuver Semont

Manuver ini diindikasikan untuk pengobatan cupulolithiasis kanan posterior. Jika kanal posterior terkena, pasien diminta duduk tegak, lalu kepala dimiringkan 450 ke sisi yang sehat, lalu secara cepat bergerak ke posisi berbaring dan dipertahankan selama 1- 
3 menit. Ada nistagmus dan vertigo dapat diobservasi. Setelah itu pasien pindah ke posisi berbaring di sisi yang berlawanan tanpa kembali ke posisi duduk lagi (Susilawathi et al., 2020).

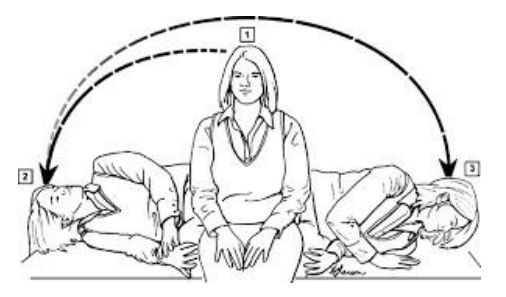

- Manuver lempert

Manuver yang paling sering digunakan tipe kanal lateral $\rightarrow$ pasien berguling 360 derajat, dimulai dari posisi supinasi, kemudian kepala pasien menoleh 90 derajat pada posisi sehat, dan diikuti dengan tubuh pasien ke arah lateral dekubitus, lalu kepala menoleh kepala diikuti tubuh kearah bawah ventral dekubitus. Kepala menoleh 90 derajat ke arah berlawanan dengan arah sehat. Setiap posisi ditahan selama 15 detik. (Edward \& Roza, n.d.)

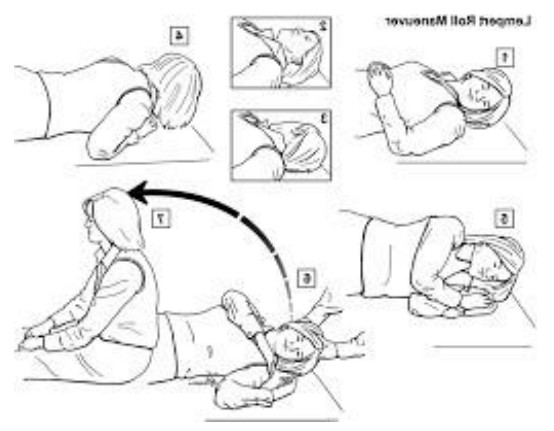

\section{Kesimpulan}

BPPV merupakan suatu kondisi terjadinya gangguan dari sistem perifer vestibular, ketika pasien merasakan sensasi pusing berputar dan berpindah yang berhubungan dengan nistagmus ketika posisi kepala berubah terhadap gaya gravitasi dan disertai gejala mual,muntah dan keringat dingin. BPPV ditandai dengan episode vertigo yang tiba-tiba dan singkat yang dipicu oleh gerakan kepala tertentu yang biasanya terjadi akibat perpindahan kristal kalsium-karbonat atau otokonia di dalam kanalis semisirkularis berisi cairan di telinga bagian dalam. Diagnosis BPPV dapat ditegakkan berdasarkan anamnesis dan pemeriksaan fisik yang meliputi beberapa tes antara lain Dix- Hallpike. Diagnosis BPPV dapat dibuat melalui riwayat klinis bersama dengan manuver diagnostik. Penatalaksanaan yang sering digunakan adalah nonfarmakologis yang meliputi beberapa manuver seperti Epley, manuver Semount dan manuver Lempert. 


\section{BIBLIOGRAFI}

Arinda, F., Yusuf, H., \& Wardhana, I. M. B. W. (n.d.). Vertigo Perifer Dan Vertigo Sentral: Laporan Kasus. Google Scholar

Balatsouras, D. G., Koukoutsis, G., Fassolis, A., Moukos, A., \& Apris, A. (2018). Benign paroxysmal positional vertigo in the elderly: current insights. Clinical Interventions in Aging, 13, 2251. Google Scholar

Dewi, Y. A., \& Mkes, S. K. (2019). Buku Tht. Bandung: Departemen Ilmu Kesehatan THT-KL FKUP/RSHS. Google Scholar

Edward, Y., \& Roza, Y. (2014). Diagnosis dan Tatalaksana Benign Paroxysmal Positional Vertigo (BPPV) Horizontal Berdasarkan Head Roll Test. Jurnal Kesehatan Andalas, 3(1). Google Scholar

Istiqomah, W. G., Sinta, M., \& Kusumaningsih, D. (2021). Penatalaksanaan Pada Benign Paroxysmal Positional Vertigo (BPPV). Google Scholar

Lee, S.-H., \& Kim, J. S. (2010). Benign paroxysmal positional vertigo. Journal of Clinical Neurology, 6(2), 51-63. Google Scholar

Picciotti, P. M., Di Cesare, T., Tricarico, L., De Corso, E., Galli, J., \& Paludetti, G. (2020). Is drug consumption correlated with benign paroxysmal positional vertigo (BPPV) recurrence? European Archives of Oto-Rhino-Laryngology, 277(6), 16091616. Google Scholar

Priyono, A. H., \& Nusadewiarti, A. (2020). Family Medicine Approach sebagai Tatalaksana Benign Paroxysmal Positional Vertigo (BPPV) Kanal Posterior Kanan Komorbid Hipertensi pada Perempuan Usia 49 Tahun: Sebuah Laporan Kasus. SCRIPTA SCORE Scientific Medical Journal, 1(2), 10. Google Scholar

Putri, C. M., \& Sidharta, B. (2016). Hubungan antara cedera kepala dan terjadinya vertigo di rumah sakit Muhammadiyah lamongan. Saintika Medika, 12(1), 1-6. Google Scholar

Rachmawati, R. C., Imtinan, I., Santoso, L. P., Puput, P. S., Setyaningrum, S., \& Asih, W. S. (2021). Identifikasi Kelimpahan Invertebrata di Pantai Marina Semarang, Kota Semarang, Jawa Tengah. Seminar Nasional Sains \& Entrepreneurship, 1(1). Google Scholar

Risa, A. N., \& Fauziah, E. (2021). Penatalaksanaan Fisioterapi Untuk Mengurangi Vertigo Pada Penderita Benign Paroxysmal Positional Vertigo (Bppv) Dengan Teknik Semont Liberatory Maneuver Di Kelurahan Sungai Andai Kota Banjarmasin. Jurnal Kajian Ilmiah Kesehatan Dan Teknologi, 3(1), 1-6. Google Scholar

Soepardi, E. A., Iskandar, N., Bashiruddin, J., \& Restuti, R. D. (2007). Buku ajar ilmu kesehatan telinga hidung tenggorok kepala \& leher. Jakarta Balai Penerbit FK UI. Google Scholar

Susilawathi, N. M., Tini, K., Wijayanti, I. A. S., Rahmawati, P. L., Sudira, P. G., Wardhana, D. P. W., \& Samatra, D. P. G. P. (2020). Tata Laksana Pemeriksaan Neurologis Virtual Di Era Pandemi Corona Virus Disease 2019. Callosum Neurology, 3(3), 102-112. Google Scholar

Threenesia, A., \& Iyos, R. N. (2016). Benign Paroxysmal Positional Vertigo (BPPV). 
Alifia Firdiansari

Medical Journal of Lampung University [MAJORITY], 5(5), 108-112. Google Scholar

Triandini, E., Jayanatha, S., Indrawan, A., Putra, G. W., \& Iswara, B. (2019). Metode Systematic Literature Review untuk Identifikasi Platform dan Metode

Pengembangan Sistem Informasi di Indonesia. Indonesian Journal of Information Systems, 1(2), 63-77. Google Scholar

First publication right:

Jurnal Syntax Fusion: Jurnal Nasional Indonesia

This article is licensed under:

(c) (†) (?) 